\title{
Effect of Edible Coating Containing Pomegranate Peel Extract on Quality and Shelf Life of Silver Carp (Hypophthalmichthys molitrix) Fillet during Refrigerated Storage
}

\section{Tarkhasi A*}

Independent Researcher, Iran

\begin{abstract}
Effects of edible coating containing pomegranate peel extract (PPE) on the quality and shelf life of silver carp fillet during refrigerated storage were investigated. Freshly fish fillet were assigned to three treatments: control (fillet treated with edible coating and no antioxidants); fillet treated with edible coating and 5\% PPE (T1) and fillet treated with edible coating and $10 \%$ PPE (T2). Chemical ( $\mathrm{pH}$, peroxide value and thiobarbituric acid) and microbiological (total viable count and psychrotrophic count) analysis were used to evaluated the effect of this treatments during refrigerated storage. The results show that addition of PPE considerably delayed lipid oxidation in silver carp fish fillet in T1 and T2 compared control samples. According to microbiological assay, T1 and T2 samples at days 12 reached to maximum acceptability limit while it was happened in day 9 for control samples. There were significant differences $(P<0.05)$ between treated and control samples at all the days during the refrigerated storage.
\end{abstract}

Keywords: Pomegranate peels extract; Edible coating; Shelf life; Silver carp

\section{Introduction}

It is well known that many undesirable changes such as microbial spoilage and lipid oxidation can be occurred during refrigerated storage of meat. Minimizing contamination and retarding or inhibiting the growth of spoilage is very important for improving fresh meat shelf life and quality [1]. Fish contain high protein sources, hydrosoluble and liposoluble vitamins, minerals, polyunsaturated fatty acids (PUFAs) and relatively large quantities of free amino acids. Unsaturated fatty acids are highly susceptible to oxidation, resulting in off-flavors and structural changes which are unappealing to consumers $[2,3]$. Some complex process such as chemical, microbiological and physical changes have occurred during storage of fish. These reactions are usually responsible for the initial loss of freshness, obvious spoilage and thereby degrade product shelf life and quality of fish $[4,5]$. Nevertheless, toxicological effects [6] together with consumer preference for natural products have resulted an increased interest in the search and utilize for natural antioxidants in fruits and vegetables that maybe help attenuate oxidative processes [7]. Plants contain high antioxidant capacity and some phytochemicals such as polyphenols, mainly phenolic acids and flavonoids that exhibited antioxidant activity [8].

The deleterious effect of lipid oxidation on food is retarded with the application of antioxidant agents and natural preservation. Furthermore, lipid oxidation can be effectively reduced by choosing films and coatings of limited oxygen permeability [9]. Recently, natural antioxidants and preservation have become very popular for food application and are preferred by consumers than synthesized antioxidants. Among these, pomegranate fruit and its derivate products have been shown to be effective in retarding the process of lipid oxidation in both in vitro and in vivo assays [10-12]. It is reported that pomegranate peel is rich source of tannins and other phenolic and flavonoids compounds which have remarkable antimicrobial and antioxidant activity [13-16]. The antioxidant activity exhibited by phenolic compounds has been reported in fresh as well as in processed meat in terms of reduced lipid oxidation [17-20]. The antimicrobial activity of pomegranate fruits and its peel extract have been demonstrated for several pathogens such as Escherichia coli, Staphylococcus aureus, including several methicillin resistant strains, Vibrio cholerae and Bacillus subtilis [21-30]. The objectives of this study were to evaluate the effects of edible coating containing pomegranate peel extract on the quality and shelf life of silver carp fillet during refrigerated storage.

\section{Material and Methods}

\section{Preparation of samples}

Preparation of treatments: Fresh silver carp (Hypophthalmichthys molitrix) were purchased from a local market in Zabol, Iran and transported to fishery lab during $30 \mathrm{~min}$ in ice. Samples were washed, cleaned, gutted and the filleted into needed slices (100 g/average weight/fillet) by hand. Then the mixture of edible coating was prepared $(60 \%$ cool water $+30 \%$ wheat flour $+10 \%$ corn flour $)$. First thin layer of edible coating mixture spread on fillets by hand and then the concentrations of $5 \%$ and $10 \%$ of PPE spray on fillets by syringe. Three treatments were prepared: control (fillet treated with edible coating and no antioxidants); fillet treated with edible coating and 5\% PPE (T1) and fillet treated with edible coating and 10\% PPE (T2). 21 fillets from each sample were prepared, and then all of samples were packed and placed in the refrigerator. For each treatment three replicates were considered.

Preparation of pomegranate peel powder: Mature pomegranate fruit, variety "shishe kap", having no visible external cuts or spoilage was purchased from the central fruit market (Mashhad, Iran). To obtain the pomegranate peel, the pomegranate fruits were peeled manually and dried in air for $48 \mathrm{~h}$. Dried pieces were powdered in heavy duty kitchen grinder and stored in freezer $\left(-18^{\circ} \mathrm{C}\right)$.

\section{Preparation of extraction}

About $10 \mathrm{~g}$ of dried rind powder was mixed with $100 \mathrm{ml}$ of $50 \%$

*Corresonding author: Tarkhasi A, Independent Researcher, Iran, Tel 2544043145; E-mail: a.tarkhasi@gmail.com

Received January 21, 2016; Accepted July 29, 2016; Published August 12, 2016

Citation: Tarkhasi A (2016) Effect of Edible Coating Containing Pomegranate Peel Extract on Quality and Shelf Life of Silver Carp (Hypophthalmichthys molitrix) Fillet during Refrigerated Storage. J Food Ind Microbiol 2: 112. doi:10.4172/25724134.1000112

Copyright: (c 2016 Tarkhasi A. This is an open-access article distributed under the terms of the Creative Commons Attribution License, which permits unrestricted use, distribution, and reproduction in any medium, provided the original author and source are credited. 
methanol. $20 \mathrm{ml}$ Diethyl plus acetic acid 1\% was added to mixture to remove pigment and fat. Keep it on a magnetic stirrer overnight at room temperature. Centrifuge the contents at $3000 \mathrm{~g}$ for $10 \mathrm{~min}$ and collect the supernatant. Repeat extraction with the same solvent by stirring on a magnetic stirrer for overnight. After centrifugation the first supernatant was combined with the second one. Solvent was filtered by whatman filter paper, NO.4 when the floating particles were seen on the surface. Evaporated methanol from the solution under vacuum at approximately $42^{\circ} \mathrm{C}$ by using a rotary-evaporator (Makkar, 2000).

\section{Determination of total phenolic content}

$200 \mathrm{mg}$ of dried rind powder was mixed with $10 \mathrm{ml}$ of $50 \%$ methanol. The solution was thoroughly shaken at room temperature for $24 \mathrm{~h}$ and centrifuged at $3000 \mathrm{~g}$ for $20 \mathrm{~min}$, and the supernatant was removed (Makkar, 2000). Total phenolic content in the pomegranate extracts were determined with Folin-Ciocalteu reagent by the of Singleton method [31] using tannic acid as a standard phenolic compound. Briefly, $1 \mathrm{ml}$ of extract solution contains was mixed with $45 \mathrm{ml}$ of distilled water. One milliliter of Folin-Ciocalteu reagent was added and the content of the flask mixed thoroughly. After $3 \mathrm{~min} 3 \mathrm{ml}$ of $\mathrm{Na}_{2} \mathrm{CO}_{3}$ was added and then the mixture was allowed to stand for $2 \mathrm{~h}$. The absorbance was measured at $760 \mathrm{~nm}$ using a UV spectrophotometer (PG Instruments Ltd T80+, UK). The concentration of total phenolic compounds in pomegranate peel extracts was determined as microgram of tannic acid equivalent by using an equation that was obtained from the standard tannic acid graph.

\section{Determination of DPPH radical scavenging activity}

The ability to scavenge 1, 1-diphenyl-2-picrylhydrazyl (DPPH) radical by PPE estimated by the method of [32]. $1 \mathrm{ml}$ of extraction was mixed with $1 \mathrm{ml}$ of DPPH $(500 \mu \mathrm{M})$ with vigorous shaking. The reaction mixture was stored in the dark at room temperature for $20 \mathrm{~min}$ and then absorbance was measured at $517 \mathrm{~nm}$ using a UV spectrophotometer (PG Instruments Ltd T80+, UK). The antioxidant activity was calculated by the following equation:

\section{Antioxidant activity: $\left(\frac{1-\text { Asample }(517 \mathrm{~nm})}{\text { Acontrol(517nm) }}\right) * 100$ \\ Chemical analysis}

ph: The $\mathrm{pH}$ of the each treatment was determined by blending 5 $\mathrm{g}$ of sample with $45 \mathrm{ml}$ distilled water for $30 \mathrm{~s}$ in a homogenizer (NO. NS-2600M, China). The $\mathrm{pH}$ values were measured using a standardized electrode attached to a digital $\mathrm{pH}$ meter (Multiline $\mathrm{P} 4 \mathrm{Wtw}$, Germany) [33].

Thiobarbituric acid reactive substances: The thiobarbituric acid reactive substances (TBARS) value (mg malon aldehyde/ $\mathrm{kg}$ ) of the fish fillet was determined colorimetrically using the method described by Egan et al (1997).

Peroxide value (PV): Peroxide value analysis of the each treatment (mili/eqi $\mathrm{O}_{2} / \mathrm{kg}$ fish fat) was determined using the method described by AOAC [34].

\section{Microbial analysis}

10 grams of fish fillet were aseptically homogenized for $1 \mathrm{~min}$ in $90 \mathrm{ml}$ of sterilized $85 \% \mathrm{NaCl}$ sasline using a stomacher Lab Blender (Bosch, Germany). From this homogenate Serial decimal dilutions were made $\left(10^{-2}, 10^{-3}, 10^{-4}, 10^{-5}, 10^{-6}\right)$ in $85 \% \mathrm{NaCl}$ saline solution, and then used for microbiological analysis for fish samples at each of the appropriate time intervals during refrigerated storage.
Total viable counts (TVC) were determined in plate count agar by the spread plate method [35] by inoculating $0.1 \mathrm{ml}$ of the sample homogenate, at selected dilutions, onto duplicate sterile plates of pre poured and dried Standard Method Agar (Nissui Pharmaceutical Co., Ltd., Tokyo, Japan) using the surface spread technique, then the plates were incubated for $48 \mathrm{~h}$ at $35^{\circ} \mathrm{C}$.

Psychrotrophic count (PTC) was determined in a similar method to that for TVC except that plates were incubated at $4^{\circ} \mathrm{C}$ for 10 days [36].

\section{Statistical analysis}

The obtained Data were analyzed by ANOVA one way test, using the SPSS software for windows (version 16.0). Tukey's multiple range tests for chemical and microbial quality were used. Three replications of the study were performed and measurements of all parameters. Mean values for various parameters were calculated and compared by analysis of variance using the SPSS. Statistical significance was identified at the $95 \%$ confidence level $((\mathrm{P}<0.05)$. The average values were reported along with standard deviation ( \pm Standard Deviation).

\section{Results and Discussion}

\section{The total phenolic content and DPPH free radical scavenging activity of PPE}

The total phenolic content and was $262.5 \mathrm{mg}$ TAE/g sample, and The DPPH free radical scavenging activity (\% scavenging activity) was $87 \%$ using methanol $50 \%$ as solvent. It is clearly obvious that the presence of the phenolic compounds in this extract is an important factor in creating the antioxidant activity of them. The phenolic and flavonoid contents can be used as an important indicators of antioxidant capacity which and be used as a preliminary screen for any product when intended as a natural source of antioxidants in functional foods. Kim et al. (2002) introduced the peel of pomegranate as a rich source of antioxidants and phenolic materials. Undoubtedly, the antioxidant capacity of pomegranate is related to the presence of phenolic materials, especially elagic acid and punicalagin [37]. Pomegranate peel, also, had been shown to be rich in polyphenols [38]. Singh et al. [39] extracted antioxidants from pomegranate peel and seed with the use of methanol, acetone or water and found that methanol gave maximum antioxidant yield. TomasBarberan et al. [40] reported that peel tissue usually contained larger amount of phenolics, anthocyanins and flavonols compound. A linear relationship between total phenolic content, antioxidant capacity and antibacterial activity against several microorganisms has been shown [29]. Antimicrobial activities of phenolic compounds may involve multiple modes of action. Phenolic compounds can denature enzymes [41], but they can also bind to substrates such as minerals, vitamins and carbohydrates making them unavailable for microorganisms $[42,43]$. Furthermore, phenols can be absorbed to the cell wall, resulting in a disruption of the membrane structure and function (Hugo and Bloomfield, 1971). [44,45] have reported that radical Scavenging activity of PPE approximately similar to these finding. Li et al. [46] have also reported that pomegranate peel extract has high potential antioxidant activity and reported that total phenolic content about $249.4 \mathrm{mg} / \mathrm{g}$, that approximately similar to these finding.

\section{Chemical analysis}

$\mathbf{p H}$ : Variations in values of $\mathrm{pH}$ during the refrigerated storage are depicted in Table 1 . The initial $\mathrm{pH}$ of the fish sample were 6.65 in control sample and 6.61 and 6.50 in T1 and T2, respectively. No significant difference between was found treatment at day of zero. 
Then the values of $\mathrm{pH}$ slightly decreased at day 3 and then increased gradually. $\mathrm{pH}$ increased slowly during the refrigerated storage. It was significantly difference $(p<0.05)$ between groups in all days of storage. Control sample at days of 15 was a highest value but value of $\mathrm{pH}$ in $\mathrm{T} 1$ and $\mathrm{T} 2$ were lower than of control treatment because of treated $\mathrm{T} 1$ and T2 with PPE and edible coating. Similar results for, the initial $\mathrm{pH}$ of the silver carp fillet have been reported by fan et al. and $\mathrm{Xu}$ et al. $[47,48]$. The initial decrease of $\mathrm{pH}$ maybe attributed to the decomposition of glycogen in whole fish, but many researchers attributed it to the dissolution of CO2 in the fish sample for fish fillets [47,49], while the increase of $\mathrm{pH}$ was postulated to be due to an increase in volatile bases products, e.g. ammonia and tri methyl amine, by either endogenous or microbial enzymes [50,51]. Similar observations were made by Alasalvar et al. and Manju, et al. [49,52].

Thiobarbituric acid (TBA): Changes in TBA value are shown in Table 2. In this study, the initial TBA value of the control, T1 and T2 sample was $0.089,0.086$ and $0.085 \mathrm{mg} \mathrm{MDA} / \mathrm{kg}$, respectively. This value increased to 0.91 (control), 0.72(T1) and 0.64(T2) $\mathrm{mg} \mathrm{MDA} / \mathrm{kg}$ after 15 days of the storage period. The results showed that control samples were significantly $(\mathrm{p}<0.05)$ higher than the value of the T1 and T2 sample during the refrigerated storage. The data revealed that the T1 and T2 sample, which contained edible coting and PPE, showed a preservation effect on fish flesh by inhibiting the oxidation of lipid. According to Connell [53], TBA values of $1-2 \mathrm{mg} \mathrm{MDA} / \mathrm{kg}$ of fish flesh are usually regarded as the limit beyond which fish will normally develop an objectionable odor. In the present, research T1 and T2 sample didn't exceed the maximal permissible limit of $1-2 \mathrm{mg} \mathrm{MDA} / \mathrm{kg}$ in the fish muscle, but control sample reached approximately to $1 \mathrm{mg} \mathrm{MDA} / \mathrm{kg}$ at the end of storage period. Increase in TBA in all treatment during refrigerated storage may be attributed to the partial dehydration of fish and the increase oxidation of unsaturated fatty acid [54]. This observation was similar to the result [47-49,55]. A similar finding related antioxidant effect of PPE had been reported [18,11]. Devatkal

\begin{tabular}{|c|c|c|c|}
\hline $\begin{array}{c}\text { Time } \\
\text { (days) }\end{array}$ & $\begin{array}{c}\text { Control (with edible } \\
\text { coting no antioxidant) }\end{array}$ & $\begin{array}{c}\text { T1(edible coating } \\
+5 \% \text { PPE) }\end{array}$ & $\begin{array}{c}\text { T2(edible coating } \\
+10 \% P P E)\end{array}$ \\
\hline 0 & $6.65 \pm 0.05^{\mathrm{Ac}}$ & $6.61 \pm 0.10^{\mathrm{Ad}}$ & $6.50 \pm 0.00^{\mathrm{Ac}}$ \\
\hline 3 & $6.53 \pm 0.15^{\mathrm{Ad}}$ & $6.50 \pm 0.10^{\mathrm{Af}}$ & $6.46 \pm 0.05^{\mathrm{Ae}}$ \\
\hline 6 & $6.79 \pm 0.05^{\mathrm{Acd}}$ & $6.74 \pm 0.01^{\mathrm{Be}}$ & $6.69 \pm 0.01^{\mathrm{Bd}}$ \\
\hline 9 & $7.00 \pm 0.10^{\mathrm{Ac}}$ & $6.80 \pm 0.01^{\mathrm{Bc}}$ & $6.73 \pm 0.02^{\mathrm{Bd}}$ \\
\hline 12 & $7.27 \pm 0.06^{\mathrm{Ab}}$ & $7.00 \pm 0.10^{\mathrm{Bb}}$ & $6.80 \pm 0.01^{\mathrm{Cb}}$ \\
\hline 15 & $7.51 \pm 0.02^{\mathrm{Aa}}$ & $7.22 \pm 0.05^{\mathrm{Ba}}$ & $7.07 \pm 0.06^{\mathrm{Ca}}$ \\
\hline
\end{tabular}

Data is expressed as mean $\pm S D(n=3)$.

Different superscript letters in the same row indicate significant differences between treatments $(A, B, C p<0.05)$.

Different superscript letters in the same columns indicate significant differences related to storage effect $(\mathrm{a}, \mathrm{b}, \mathrm{c} p<0.05)$.

Table 1: Changes in $\mathrm{pH}$ of fish sample during refrigerated storage.

\begin{tabular}{|c|c|c|c|}
\hline $\begin{array}{c}\text { Time } \\
\text { (days) }\end{array}$ & $\begin{array}{c}\text { Control (with edible } \\
\text { coting no anti-oxidant) }\end{array}$ & $\begin{array}{c}\text { T1 (edible coating } \\
+5 \% P P E)\end{array}$ & $\begin{array}{c}\text { T2 (edible coating } \\
+10 \% P P E)\end{array}$ \\
\hline 0 & $0.09 \pm 0.00^{\mathrm{Ae}}$ & $0.08 \pm 0.0^{\mathrm{Ae}}$ & $0.08 \pm 0.00^{\mathrm{Ae}}$ \\
\hline 3 & $0.12 \pm 0.02^{\mathrm{Ae}}$ & $0.11 \pm 0.01^{\mathrm{Be}}$ & $0.09 \pm 0.01^{\mathrm{Be}}$ \\
\hline 6 & $0.30 \pm 0.02^{\mathrm{Ad}}$ & $0.22 \pm 0.02^{\mathrm{Bd}}$ & $0.21 \pm 0.02^{\mathrm{Bd}}$ \\
\hline 9 & $0.59 \pm 0.04^{\mathrm{Ac}}$ & $0.48 \pm 0.01^{\mathrm{Bc}}$ & $0.38 \pm 0.02^{\mathrm{Cc}}$ \\
\hline 12 & $0.75 \pm 0.05^{\mathrm{Ab}}$ & $0.61 \pm 0.01^{\mathrm{Bb}}$ & $0.54 \pm 0.05^{\mathrm{Cb}}$ \\
\hline 15 & $0.91 \pm 0.01^{\mathrm{Aa}}$ & $0.72 \pm 0.02^{\mathrm{Ba}}$ & $0.64 \pm 0.01^{\mathrm{Ca}}$ \\
\hline
\end{tabular}

Data is expressed as mean $\pm \operatorname{SD}(n=3)$

Different superscript letters in the same row indicate significant differences between treatments $(\mathrm{A}, \mathrm{B}, \mathrm{C} p<0.05)$.

Different superscript letters in the same columns indicate significant differences related to storage effect $(\mathrm{a}, \mathrm{b}, \mathrm{c} p<0.05)$

Table 2: Changes in TBA of fish sample during refrigerated storage. et al. [11] reported that addition of PPE extract reduce autoxidation in treated sample, and also reported that presence negative correlation between total phenolic and TBA values. They showed that TBA value increased gradually and total phenolic decreased with increase in storage period [11]. A significant relation between phenolic content and antioxidant effect of pomegranate peel extract has been reported [44]. Some reports show that edible film and coating have gas barrier properties and resistant to oxygen diffusion, thus may retarded lipid oxidation [54]

Peroxide value (PV): The initial PV (meq peroxide/kg fish sample) in the control sample was 1 (Table 3 ) and increased to 15.33 at the end of storage. No significantly difference $(\mathrm{P}>0.05)$ was observed throughout first days of the storage among the different sample. PV content significantly increased $(\mathrm{P}<0.05)$ in all treatments throughout the refrigerator storage, indicating that lipid deterioration continued under the storage temperature conditions. At the end of the storage time significant differences $(\mathrm{P}>0.05)$ were observed in the $\mathrm{PV}$ between the control (15.33) and each of T1 (14.23) and T2 (12.60) samples. PV of T1 sample was also significantly higher than of T2 samples. Storage time has a significant effect on the PV for each of control and treated samples $(\mathrm{P}<0.05)$. Nonetheless the PV in all samples was below the proposed acceptable level of 10-20 meq peroxide/kg fish fat [56]. The results also showed that the highest concentration of PPE (T2) was the most effective in slow down primary peroxidation, when compared with other groups $(\mathrm{P}<0.05)$. The peroxide value provides a measure of the degree of lipid oxidation and indicates the amount of oxidized substances. These are usually hydro peroxides, which produce iodine from potassium iodide under special conditions. Hydro peroxides are the primary products of autoxidation, which themselves are odorless. However, their decay leads to the formation of a wide range of carbonyl compounds, hydrocarbons, furans and other products that contribute to the rancid taste of decaying food [57,58]. It is assumed that PPE as natural antioxidant and so edible coating on fish surface may have been resistance to oxygen diffusion, thus may have retarded lipid oxidation. Song et al. [54] reported that edible coting containing different antioxidant retarded lipid oxidation. These results are in agreement [5960 ], who found that the PV significantly increased in salmon fillet after 15 days of storage at $5^{\circ} \mathrm{C}$.

\section{Microbial analysis}

Botta defines fish spoilage as a change in a fish or fish product that makes it unsafe, less acceptable, or unacceptable to the consumer for its original intended purpose. The rate of spoilage differs among fish species because of different defense mechanisms and physical barriers like mucus in plaice which contains lysozomes to fend off intruding foreign bodies [61]

\begin{tabular}{|c|c|c|c|}
\hline $\begin{array}{c}\text { Time } \\
\text { (days) }\end{array}$ & $\begin{array}{c}\text { Control (with edible } \\
\text { coting no anti-oxidant) }\end{array}$ & $\begin{array}{c}\text { T1 (edible coating } \\
+5 \% \text { PPE) }\end{array}$ & $\begin{array}{c}\text { T2 (edible coating } \\
+10 \% P P E)\end{array}$ \\
\hline 0 & $1.00 \pm 0.20^{\mathrm{Af}}$ & $0.93 \pm 0.11^{\mathrm{Af}}$ & $0.90 \pm 0.10^{\mathrm{Af}}$ \\
\hline 3 & $3.13 \pm 0.23^{\mathrm{Ae}}$ & $2.26 \pm 0.30^{\mathrm{Be}}$ & $1.93 \pm 0.11^{\mathrm{Be}}$ \\
\hline 6 & $6.13 \pm 0.23^{\mathrm{Ad}}$ & $5.4 . \pm 0.20^{\mathrm{Bd}}$ & $4.80 \pm 0.20^{\mathrm{Cd}}$ \\
\hline 9 & $10.00 \pm 0.20^{\mathrm{Ac}}$ & $8.70 \pm 0.11^{\mathrm{Bc}}$ & $7.23 \pm 0.25^{\mathrm{Cc}}$ \\
\hline 12 & $12.00 \pm 0.20^{\mathrm{Ab}}$ & $10.20 \pm 0.20^{\mathrm{Bb}}$ & $8.06 \pm 0.11^{\mathrm{Cb}}$ \\
\hline 15 & $15.33 \pm 0.41^{\mathrm{Aa}}$ & $14.23 \pm 0.32^{\mathrm{Ba}}$ & $12.60 \pm 0.52^{\mathrm{Ca}}$ \\
\hline
\end{tabular}

Data is expressed as mean $\pm S D(n=3)$.

Different superscript letters in the same row indicate significant differences between treatments $(A, B, C p<0.05)$.

Different superscript letters in the same columns indicate significant differences related to storage effect $(a, b, c p<0.05)$

Table 3: Changes in PV of fish sample during refrigerated storage. 
Total viable count (TVC): Variations in value of TVC of different treatments during refrigerated storage are shown in Table 4.

The initial TVC $(\log 10 \mathrm{CFU} / \mathrm{g})$ in control, T1 and T2 sample was 3.93, 3.31 and 3.12, respectively (Table 4). After processing, a reduction in TVC content was observed in T1 and T2 groups. The results showed that microbiological growth was significantly $((\mathrm{P}<0.05)$ influenced by the addition of the PPE and edible coating. The fish muscle is sterile when caught, but is quickly contaminated by surface as well as intestinal bacteria, along with contamination from the aquatic environment, equipment, human handling and storage conditions. Because of these reasons, the TVC values of the three groups increased gradually at storage. The fish of the control group attained a TVC value of $8.47 \log$ CFU/g and T1 and T2, 7.33 and 7.19, respectively after 15 days storage. Microbiological acceptability limit of $7 \mathrm{log} \mathrm{CFU} / \mathrm{g}$ for raw fish [61], indicating a microbiological shelf life of about 9 days for the non-treated control samples in comparison with the shelf life of T1 and T2 was 12 days. The result showed that adding PPE and edible coating obviously delayed microbial growth and extended the shelf life of the fish. Neither treated group samples were not reached the microbiological acceptability limit during the 15 day storage and had significantly lower TVC values than the control group $((\mathrm{P}<0.05)$. The antibacterial activity of pomegranate peels may be indicative of the presence of some metabolic toxins or broad-spectrum antibiotic compounds [16]. Shan et al. [29] have reported a correlation between total phenolic and the antibacterial activity of various plant extracts, including pomegranate peels. The mechanism responsible for phenolic toxicity to microorganisms was related to reaction with sulfhydryl groups of proteins and unavailability of substrates to microorganism $[15,61]$. Compared with the control sample, PPE in treated samples decayed the growth of TVC during the storage period. There are similar reports about antimicrobial effect of natural antioxidant on quality and shelf life of fish fillet during refrigerated storage $[20,47,54]$.

Psychrotrophic count (PTC): The initial PTC $(\log 10 \mathrm{CFU} / \mathrm{g})$ in control, T1 and T2 samples was 4.78, 4.75 and 3.93, respectively (Table $5)$. There was no significant difference $(\mathrm{P}>0.05)$ between control, T1 and $\mathrm{T} 2$ samples at the beginning of storage (day 0 ). Subsequently, the PTC of all treatment increased during refrigerated storage. Significantly differences were detected in PTC content between control, T1 and T2 samples during storage. After processing, a PTC reduction was observed in $\mathrm{T} 1$ and $\mathrm{T} 2$ groups in all treatments because of difference concentration between these treatments (T1:5\% and T2:10\%). Control samples attained a PTC value of $8.62 \mathrm{log}$ CFU/g and $\mathrm{T} 1$ and $\mathrm{T} 2,8.28$ and 7.04 , respectively after 12 days storage. The result showed that adding of PPE and edible coating obviously delayed microbial growth and extended the shelf-life of the fish about

\begin{tabular}{|c|c|c|c|}
\hline $\begin{array}{c}\text { Time } \\
\text { (days) }\end{array}$ & $\begin{array}{c}\text { Control (with edible } \\
\text { coting no anti-oxidant) }\end{array}$ & $\begin{array}{c}\text { T1 (edible coating } \\
+5 \% P P E)\end{array}$ & $\begin{array}{c}\text { T2 (edible coating } \\
+10 \% P P E)\end{array}$ \\
\hline 0 & $3.93 \pm 0.02^{\mathrm{Af}}$ & $3.31 \pm 0.07^{\mathrm{Bf}}$ & $3.12 \pm 0.04^{\mathrm{Be}}$ \\
\hline 3 & $4.77 \pm 0.07^{\mathrm{Ae}}$ & $3.96 \pm 0.06^{\mathrm{Be}}$ & $3.70 \pm 0.10^{\mathrm{Cd}}$ \\
\hline 6 & $6.35 \pm 0.07^{\mathrm{Ad}}$ & $5.84 \pm 0.06^{\mathrm{Bd}}$ & $4.65 \pm 0.04^{\mathrm{Cc}}$ \\
\hline 9 & $6.86 \pm 0.07^{\mathrm{Ac}}$ & $6.37 \pm 0.14^{\mathrm{Bc}}$ & $6.14 \pm 0.14^{\mathrm{Cb}}$ \\
\hline 12 & $7.67 \pm 0.13^{\mathrm{Ab}}$ & $6.94 \pm 0.03^{\mathrm{Bb}}$ & $6.80 \pm 0.04^{\mathrm{Ca}}$ \\
\hline 15 & $8.47 \pm 0.26^{\mathrm{Aa}}$ & $7.37 \pm 0.02^{\mathrm{Ba}}$ & $7.19 \pm 0.19^{\mathrm{Ca}}$ \\
\hline
\end{tabular}

Data is expressed as mean \pm SD $(n=3)$

Different superscript letters in the same row indicate significant differences between treatments $(A, B, C P<0.05)$.

Different superscript letters in the same columns indicate significant differences related to storage effect $(\mathrm{a}, \mathrm{b}, \mathrm{c} \mathrm{P}<0.05)$

Table 4: Changes in TVC of fish sample during refrigerated storage.

\begin{tabular}{|c|c|c|c|}
\hline $\begin{array}{c}\text { Time } \\
\text { (days) }\end{array}$ & $\begin{array}{c}\text { Control (with edible } \\
\text { coting no anti-oxidant) }\end{array}$ & $\begin{array}{c}\text { T1 (edible coating } \\
\text { +5\%PPE) }\end{array}$ & $\begin{array}{c}\text { T2 (edible coating } \\
+\mathbf{1 0} \% \mathrm{PPE} \text { ) }\end{array}$ \\
\hline 0 & $4.78 \pm 0.02^{\mathrm{Ae}}$ & $4.75 \pm 0.04^{\mathrm{Ae}}$ & $3.93 \pm 0.02^{\mathrm{Be}}$ \\
\hline 3 & $5.49 \pm 0.10^{\mathrm{Ad}}$ & $4.70 \pm 0.08^{\mathrm{Bd}}$ & $4.49 \pm 0.04^{\mathrm{Bd}}$ \\
\hline 6 & $6.36 \pm 0.16^{\mathrm{Ac}}$ & $5.59 \pm 0.05^{\mathrm{Bc}}$ & $5.29 \pm 0.11^{\mathrm{Cc}}$ \\
\hline 9 & $7.05 \pm 0.11^{\mathrm{Ab}}$ & $6.85 \pm 0.04^{\mathrm{Bb}}$ & $6.41 \pm 0.12^{\mathrm{Cb}}$ \\
\hline 12 & $8.62 \pm 0.09^{\mathrm{Aa}}$ & $7.28 \pm 0.02^{\mathrm{Ba}}$ & $7.04 \pm 0.09^{\mathrm{Ca}}$ \\
\hline
\end{tabular}

Data is expressed as mean $\pm S D(n=3)$.

Different superscript letters in the same row indicate significant differences between treatments $(A, B, C p<0.05)$.

Different superscript letters in the same columns indicate significant differences related to storage effect $(\mathrm{a}, \mathrm{b}, \mathrm{c} p<0.05)$.

Table 5: Changes in PTC of fish sample during refrigerated storage.

9 days for the control 12 days for T1 and T2 samples. Similarly, [11] reported that concentration of $5 \%$ and $10 \%$ PPE had significant reduction in bacterial counts as compared to control samples. [59] reported that PTC and TVC had same growth pattern, but relatively PTC had higher growth than the TVC, approximately similar to this finding. In this regard, [16] referred that about antibacterial activity of pomegranate peels and presence of some metabolic toxins or broad spectrum antibiotic compounds and polyphenols $[44,47,61]$ reported that polyphenols played an important role in protein precipitation and enzyme inhibition of microorganisms.

\section{Conclusion}

This study demonstrated the antioxidant and antimicrobial effect of pomegranate peel extract on shelf life of silver carp fillet. The results of microbiological analyses (TVC, PTC) confirmed that pomegranate peel extract used in silver carp fillet leads to a reduction in microbial contamination during refrigerated storage, and chemical $(\mathrm{pH}$, TBA, PV) analyses indicate that pomegranate peel extract had high antioxidant activity and retarded the lipid oxidation, probably due to the presence of high phenolic content. Furthermore, it is important to note that we can utilize the by-product of the natural antioxidant in processed food products. Of course, Additional researches will be required to determine the sufficient concentration of PPE that can be used as natural preservatives in meat processing.

\section{References}

1. Abou-Taleb M (2007) Effect of combined treatment with electrolyzed $\mathrm{NaCl}$ solutions and essential oil compounds on the quality of salmon fillets during cold storage. Global Journal Biotechnology and Biochemistry 2: 54-62.

2. Ahmad I, Beg AZ (2001) Antimicrobial and phytochemical studies on 45 Indian Medicinal plants against multi-drug resistant human pathogens. Journal of Ethnopharmacology 74: 113-123.

3. Alasalvar C, Taylor KDA, Oksuz A, Garthwaite T, Alexis MN, et al. (2001) Freshness assessment of cultured sea bream (Sparus aurata) by chemical, physical and sensory methods. Food Chemistry 72: 33-40.

4. AOAC (2002) Association of Official Analytical Chemists. Official Methods of Analysis of the Association of the Official Analysis Chemists (14thedn) Washington.

5. AOAC (2005) Official Method of Analysis. Washington, DC: Association of Official Analytical Chemists (17thedn).

6. Ashie INA, Smith JP, Simpson BK (1996) Spoilage and shelf life extension of fresh fish/shellfish. Critical Reviews in Food Science and Nutrition 36: 87-122.

7. Ben NC, Ayed N, Metche M (1996) Quantitative determination of the polypheno content of pomegranate peel. Zeitschrift fur Lebensmittel-Untersuchung Und Forschung 203: 374-378.

8. Bonilla J, Atarés L, Vargas M, Chiralt A (2011) Edible films and coatings to prevent the detrimental effect of oxygen on food quality: Possibilities and limitations. Journal of Food Engineering.

9. Botta JR (1995) Evaluation of Seafood Freshness Quality. VCH Publishers Inc. 
Citation: Tarkhasi A (2016) Effect of Edible Coating Containing Pomegranate Peel Extract on Quality and Shelf Life of Silver Carp (Hypophthalmichthys molitrix) Fillet during Refrigerated Storage. J Food Ind Microbiol 2: 112. doi:10.4172/2572-4134.1000112

10. Braga L, Shupp J, Cummings C, Jett M, Takahashi JA et al. (2005) Pomegranate extract inhibits Staphylococcus aureus growth and subsequent enterotoxin production. Journal of Ethnopharmacology 96: 335-339.

11. Chidanandaiah RC, Sanyal MK (2009) Effect of sodium alginate with preservative on the quality of meat patties during refrigerated storage. Journal of Muscle Foods 20: 275-292.

12. Connell JJ (1990) Methods of assessing and selecting for quality. In control of fish quality (3rdedn) Berlin: Springer.

13. Devatkal SK, Naveena BM (2010) Effect of salt, kinnow and pomegranate fruit by-product powders on color and oxidative stability of raw ground goat meat during refrigerated storage. Meat Science 85: 306-311.

14. Devetkal KS, Jaiswal P, Jha NS (2011) Antibacterial activity of aqueous extract of pomegranate peel against Pseudomonas stutzeri isolated from poultry meat. Journal Food Science Technology.

15. Fan WJ, Chi YL, Zhang S (2008) The use of a tea polyphenol dips to extend the shelf life of silver carp (Hypophthalmicthys molitrix) during storage in ice. Food Chemistry 108: 148-15

16. Furneri PM, Marino A, Saija A, Uccella N, Bisignano G (2002) In vitro antimycoplasmal activity of oleuropein. International Journal of Antimicrobial Agents 20: 293-296.

17. Gil MI, Tomas-Barberán, FA, Hess-Pierce B, Holcroft DM, et al. (2000) Antioxidant activity of pomegranate juice and its relationship with phenolic composition and processing. Journal of Agriculture and Food Chemistry 48: 4581-4589.

18. Gonza lez-Fandos E, Villarino-Rodrı guez A, Garcı a-Linares MC, Garcı a-Arias MT, Garcı a-Fernandez MC (2005) Microbiological safety and sensory characteristics of salmon slices processed by the sous vide method. Food Control 16: 77-85.

19. Gram L, Huss HH (1996) Microbiological spoilage of fish and fish products. International Journal of Food Microbiology 33: 121-137.

20. Guevara JM, Chumpitaz J, Valencia E (1994) The in vitro action of plants on Vibrio cholerae. Revista de gastroenterologia Del Peru: organo oficial de la Sociedad de Gastroenterologia Del Peru 14: 27-31

21. Hozbor MC, Saiz Al, Yeannes MI, Fritz R (2006) Microbial changes and its correlation with quality indices during aerobic iced storage of sea salmon (Pseudopercis semifasciata). LWT-Food Science and Technology 39: 99-104.

22. Huss HH (ed.) (1995) Quality and quality changes in fresh fish. Food and Agriculture Organization (FAO) of the United Nations, Fisheries Technical Paper.

23. Jeon YJ, Kamil JYVA, Shahidi F (2002) Chitosan as an Edible Invisible Film for Quality Presevation of Herring and Atlantic Cod, Journal Agriculture of Food Chemistry 50: 5167-5178.

24. Jo C, Son Jh, Sohn CB, Byun MW (2003) Functional properties of raw and cooked pork patties with added irradiated, freeze-dried green tea leaf extract powder during storage at $4^{\circ} \mathrm{C}$. Meat Science 64: 13-17.

25. Kenawi MA, Abdel Salam, RR, Kenawi MN (2009) Effect of antimicrobial agents on some chemical and microbiological characteristics of vacuum - packaged ground buffalo meat stored under refrigerated condition. Biotechnology in Animal Husbandry 25: 231-239.

26. Li Y, Guo C, Yang J, Wei J, Xu J, et.at. (2005) Evaluation of antioxidant properties of pomegranate peel extract in comparison with pomegranate pulp extract. Food Chemistry. 96: 254-260.

27. Lu F, Liu DH, Ye XQ (2009) Alginate-calcium coating incorporating nisin and EDTA maintains the quality of fresh northern snakehead (Chana argus) fillets stored at $4^{\circ} \mathrm{C}$. Journal Science Food Agriculture 89: 848-854.

28. Machado TD, Leal ICR, Amaral, ACF, dos Santos KRN, et al. (2002) Antimicrobial ellagitannin of Punica granatum fruits. Journal of the Brazilian Chemical Society 13: 606-610.

29. Machado T, Pinto A, Pinto M, Leal I, Silva M, et al. (2003) In vitro activity of Brazilian medicinal plants, naturally occurring naphthoquinones and their analogues, against methicillin-resistant Staphylococcus aureus. International Journal of Antimicrobial Agents 21: 279-284.

30. Manju S, Leema J, Srinivasa Gopal TK, Ravishankar CN, Jose L (2007) Effect of sodium acetate dip treatment and vacuum-packaging on chemical, microbiological, texture and sensory changes of Pearspot (Etroplus suratensis) during chill storage. Food Chem 102: 27-32.
31. Manat C, Soottawat B, Wonnop V, Cameron F (2005) Changes of pigments and color in sardine (Sardinella gibbosa) and mackerel (Rastrelliger kanagurta) muscle during iced storage. Food Chemistry 93: 607-617.

32. Melendez PA, Capriles VA (2006) Antibacterial properties of tropical plants from Puerto Rico. Phytomedicine 13: 272-276.

33. McCarrell E, Gould S, Fielder M, Kelly A, El Sankary W, et at. (2008) Antimicrobial activities of pomegranate rind extracts: enhancement by addition of metal salts and vitamin C. BMC Complementary and Alternative Medicine 8: 64 .

34. McFaddin JF (2000) Biochemical Tests for Identification of Medical Bacteria (7ndedn) Baltimore, Williams and Wilkins.

35. Naveena BM, Muthukumar M, Sen AR, Babji Y, Murthy TRK (2006) Improvement of shelf-life of buffalo meat using lactic acid, clove oil and vitamin $\mathrm{C}$ during retail display. Meat Science 74: 409-415.

36. Naveena BM, Sen AR, Vaithiyanathan S, Babji Y, Kondaiah N (2008) Comparative efficacy of pomegranate juice, pomegranate rind powder extract and $\mathrm{BHT}$ as antioxidants in cooked chicken patties. Meat Science 80: 1304 1308.

37. Naveena BM, Sen AR, Kingsly RP, Singh DB, Kondaiah N (2008) Antioxidant activity of pomegranate rind powder extract in cooked chicken patties. International Journal of Food Science \& Technology 43: 1807-1812.

38. Naz S, Siddiqi R, Ahmad S, Rasool S, Sayeed S (2007) Antibacterial activity directed isolation of compounds from Punica granatum. Journal of Food Sciences 72: 341-345

39. Negi PS, Jayaprakasha GK, Jena BS (2002) Antioxidant and anti-mutagenic activities of pomegranate peel extracts. Food Chemistry 80: 393-397.

40. Negi PS, Jayaprakasha GK (2003) Antioxidant and antibacterial activities of Punica granitum peel extracts. Journal of Food Science 68: 1473-1477.

41. Noda Y, Kaneyuka T, Mori A, Packer L (2002) Antioxidant activities of pomegranate fruit extract and its anthocyanidins: delphinidin, cyanidin, and pelargonidin. Journal of Agricultural and Food Chemistry 50: 166-171.

42. Ojagh SM, Rezaei M, Razavi SH, Hosseini SMH (2010) Effect of chitosan coatings enriched with cinnamon oil on the quality of refrigerated rainbow trout Food Chemistry 120: 193-198.

43. Ólafsdóttir G, Martinsdottir E, Oehlenschlager J, Dalgaard P, Jensen B, et al. (1997) Methods to evaluate fish freshness in research and industry. Trends in Food Science \&Technology 8: 258-265.

44. Ozkal N, Dinc S (1994) Evaluation of the pomegranate (Punica granatum L.) peels from the standpoint of pharmacy. Ankara Univ Eczacilik Fak Derg 22 21-29.

45. Pérez-Jiménez J, Arranz S, Tabernero M, Díaz-Rubio ME, Serrano J, et al. (2008) Updated methodology to determine antioxidant capacity in plant foods oils and beverages: Extraction, measurement and expression of results. Food Research International 41: 274-285.

46. Poyrazoglu E, Gökmen V, Artık N (2002) Organic acids and phenolic compounds in pomegranates (Punica granatum L.) grown in Turkey. Journal of Food Composition and Analysis 15: 567-575.

47. Prashanth D, Asha MK, Amit A (2000) Antibacterial activity of Punica granatum. Fitoterapia 72: 171-173.

48. Püssa T, Raudsepp P, Toomik P, Pällin R, Mäeorg, et al. (2009) A study of oxidation products of free polyunsaturated fatty acids in mechanically debonedmeat. Journal of Food Composition and Analysis 22: 307-314.

49. Reddy M, Gupta S, Jacob M, Khan S, Ferreira D (2007) Antioxidant, antimalarial and antimicrobial activities of tannin-rich fractions, ellagitannins and phenolic acids from Punica granatum L. Planta Medica 73: 461-467.

50. Ruiz-Capillas C, Moral A (2001) Residual effect of CO2 on hake (Merluccius merluccius L.) stored in modified and controlled atmospheres. European Food Research and Technology 212: 413-420.

51. Sallam KI, Samejima K (2004) Microbiological and chemical quality of ground beef treated with sodium lactate and sodium chloride during refrigerated storage. LWT Food Sci Techno 37: 865-71.

52. Sánchez-Alonso I, Borderias A (2008) Technological effect of red grape antioxidant dietary fiber added to minced fish muscle. Journal of Food Science and Technology 43: 1009-1018. 
Citation: Tarkhasi A (2016) Effect of Edible Coating Containing Pomegranate Peel Extract on Quality and Shelf Life of Silver Carp (Hypophthalmichthys molitrix) Fillet during Refrigerated Storage. J Food Ind Microbiol 2: 112. doi:10.4172/2572-4134.1000112

53. Sarkhosh A, Zamani Z, Fatahi R, Ghorbani H, Hadian J (2007) A review on medicinal characteristics of pomegranate. J Med Plants 6: 13-24.

54. Shahidi F, Naczk M (2004) Phenolics in food and nutraceuticals. Boca Raton FL: CRC Press.

55. Shan B, Cai YZ, Brooks J, Corke H (2007) The in vitro antibacterial activity of dietary species and medicinal herb extracts. International Journal of Food Microbiology 117: 112-119.

56. Shewan JM (1961) The microbiology of Sea water fish. Fish as Food 1: $487-$ 560

57. Singh RP, Murthy KNC, Jayaprakasha GK (2002) Studies on the antioxidant activity of pomegranate peel and seed extracts using in vitro models. Journal of Agricultural and Food Chemistry 50: 81-86.
58. Singleton VL, Orthofer R, Lamuela-Ravento's RM (1999) Analysis of total phenols and other oxidation substrates and antioxidants by means of FolinCiocalteau reagent. Methods in Enzymology 299: 152-178.

59. Song Y, Lei SB, Huixing A, Yongkang $L$ (2010) Effect of sodium alginate-based edible coating containing different anti-oxidants on quality and shelf life of refrigerated bream (Megalobrama amblycephala). Food Control 22: 608-615.

60. Stern JL, Hagerman AE, Steinberg PD, Mason PK (1996) Phlorotannin protein interactions. Chemical Ecology 22: 1887-1899.

61. Tomas-Barberan FA, Gil MI, Cremin P, Waterhouse AL, Hess-Pierce $B$, et al. (2001) HPLC-DAD-ESIMS analysis of phenolic compounds in nectarines, peaches, and plums. Journal of Agricultural and Food Chemistry 49: 4748-4760. 